\title{
Utilizing genomics to understand and respond to global climate change
}

\author{
Justin Borevitz
}

Correspondence: Justin.borevitz@ anu.edu.au

Research School of Biology, Australian National University, Canberra, Australia

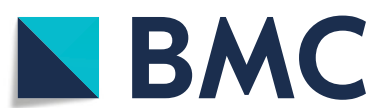

C The Author(s). 2021 Open Access This article is licensed under a Creative Commons Attribution 4.0 International License, which permits use, sharing, adaptation, distribution and reproduction in any medium or format, as long as you give appropriate credit to the original author(s) and the source, provide a link to the Creative Commons licence, and indicate if changes were made. The images or other third party material in this article are included in the article's Creative Commons licence, unless indicated otherwise in a credit line to the material. If material is not included in the article's Creative Commons licence and your intended use is not permitted by statutory regulation or exceeds the permitted use, you will need to obtain permission directly from the copyright holder. To view a copy of this licence, visit http://creativecommons.org/licenses/by/4.0/. The Creative Commons Public Domain Dedication waiver (http://creativecommons.org/publicdomain/zero/1.0/) applies to the data made available in this article, unless otherwise stated in a credit line to the data. 
networks could be distilled that process dirt into soil and begin to reverse the degradation of once fertile landscapes. Natural genomics experiments are under way in every living system, and new studies will reveal those repeatable evolutionary steps that lead to successful biological innovations.

This ongoing collection of papers in Genome Biology will be a treasure trove of studies attacking big problems with new technological solutions. Some early highlights include temperature and transposons responses in Arabidopsis, thermal and drought selection on standing variation in Drosophila and maize, as well as a prospectus on applications of CRISPR to crops of the future. We welcome further Genome papers from farther afield that deal with climate adaptation, mitigation, and resilience across novel organisms and ecosystems that aim to make direct and/or predictive links to the solutions we urgently need.

Author's contributions

The author read and approved the final manuscript.

\section{Declarations}

Competing interests

The author declares no competing interests.

Published online: 29 March 2021

\section{Publisher's Note}

Springer Nature remains neutral with regard to jurisdictional claims in published maps and institutional affiliations.

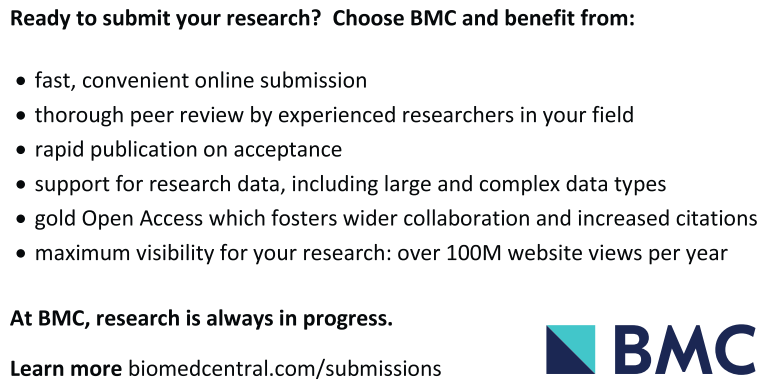

